\title{
Analysis of Brand Awareness, Customer Satisfaction and Perceived Quality on the Brand Loyalty in the Bottled Water Consumer (AMDK) SINARMAS PRISTINE Brand
}

\author{
Christiana Fransiska Sembiring, \\ Master of Management Student Mercu Buana University, \\ Jakarta, Indonesia \\ Irham Abdul Azis \\ Master of Management Student Mercu Buana University, \\ Jakarta, Indonesia
}

\begin{abstract}
Pristine is a new product that puts the target market from premium to premium consumer mess smaller than regular AMDK products. Pristine pH $8+$ that can neutralize acid effluent bodies. This research focuses on analyzing brand awareness, customer Satisfaction and perceived quality against the brand loyalty of bottled water consumers in the package (AMDK) SINARMAS Pristine brand. The type of research used in this study is descriptive research using quantitative methods. The population in this research is the community in Jakarta and its surroundings with samples taken as many as 66 respondents. The collection of data on this research uses questionnaires distributed to respondents using incidental sampling techniques. The results of this study showed that Simultaneous analysis results showed that the variables of brand awareness, customer satisfaction, and perceived quality have a significant effect on the brand loyalty consumer AMDK brand Pristine.
\end{abstract}

Keywords:- Brand Awareness; Customer satisfaction, Perceived Quality; Qualitative approaches; AMDK Pristine.

\section{INTRODUTION}

Along with the growing number of people in Indonesia, the needs of drinking water continue to increase, so the chances of drinking water in the packaging (AMDK) prospects are getting better. Coupled with increasing public awareness about healthy living, the need for quality drinking water is increasing as well. According to (Tjiptono, 2005) describes the existence of a brand of bottled drinking water in the minds of consumers who have been affected by integrated promotional activities and increased brand awareness is a successful brand of bottled drinking water in order to expand the market. This behavior attracts many business actors to compete in making bottled drinking water products that have more function than the usual drinking water, such as high $\mathrm{pH}$ drinking water (alkali), oxygenated drinking water and demineral drinking water.

\author{
Fachry Rendy Pradika \\ Master of Management Student Mercu Buana University, \\ Jakarta, Indonesia \\ Nurhadi \\ Master of Management Student Mercu Buana University, \\ Jakarta, Indonesia
}

One brand of drinking water that has a high $\mathrm{pH}$ is Pristine $8+$, established since 2006 Pristine $8+$ becomes an alkaline drinking water brand for the first time in Indonesia. According to research conducted by (Satria et al., 2016) alkaline water is water that has the properties of subtle, energy, cleansing that has a unique combination of water characteristics. This water is also micro which has the ability of absorption by an unparalleled body. Rich in alkaline minerals, assists in buffering of acidic conditions in the body. Pristine $8+$ is a mineral water ionization that provides added value in the form of a $\mathrm{pH}$ base that can help neutralize acids in the body and have antioxidant properties of high mineral content, it can help the body's metabolic process to become redundant.

In the last five years already many outstanding brands of drinking water with high $\mathrm{pH}$ because it provides benefits can neutralize acidic substances in the body. The main problem is that consumers are still many who do not know the benefits of Pristine drinking water $8+$ for health and other problems are consumers still assume that all mineral water has the same benefits.

According to (Kotler \& Keller, 2013), the brand is a distinctive feature in which there is a symbol, sign, term, name, and design, or a combination of all for the differentiator of other competitors. The brand used to be a strong differentiation tool of competitors (Pappu et al., 2005). Brands are an important element in conducting marketing activities because brands are a hallmark of the company to market their products and give consumers an interest in purchasing products and services (Hasugian, 2015). Strong brands can provide excellence in competition (Lee \& Ki, 2010), create premium prices, profitability and provide customer loyalty (Madden et al., 2006), and also support brand expansion opportunities (Yasin et al., 2007). This causes the brand strength is very important for the company, so consumers have an interest in buying those products and services. According to (Kotler \& Keller, 2013) Material considerations in creating marketing strategies formed brand strength so as to provide useful 
information and brand strength influenced by brand equity. This is what makes the authors do research with the title "Analysis brand awareness, customer Satisfaction and perceived quality against the brand loyalty of bottled water consumers in the package (AMDK) SINARMAS Pristine brand".

\section{LITERATURE REVIEW}

\section{A. Brand Equity}

According to (Aaker, 1997) brand equity is the name or symbol of a particular brand that is a group of assets in a product or service by adding or subtracting value for a company or its customers (Aaker, 1997). Furthermore, (Kotler \& Keller, 2013) state that the size of brand equity is closely related to customer loyalty. It aims to meet one's needs so that they buy back or do not do it so that it is closely related to customer loyalty. According to (Aaker, 1997) in terms of consumers and companies, brand equity has a visible role. For most consumers, brand equity can add or subtract from a perceived value. Whereas the company can help increase the amount of cash flow by adding the value of products or services provided to consumers.

Keller's Customer-Based Brand Equity (CBBE) model in (Mariadi \& Aima, 2014) illustrates a process for building a strong brand. The model explains the six dimensions of brand equity, namely: (1) Brand salience, with regard to aspects of brand awareness, such as characteristics, brand ease to be remembered and recognized. (2) Brand performance, with regard to the ability of products or services to meet consumer needs that are broadly divided into five main attributes and benefits that underlie brand performance, namely: primary elements and supplement features; product reliability, durability, and serviceability; effectiveness, efficiency and empathy of service; model and design; price. (3) Brand imagery, with regard to extrinsic properties of a product or service, that is, the ability of the brand to meet the customer's psychological or social needs, where the brand imagery can be formed either directly or indirectly. The four categories of brand imagery include: consumer profiles, buying and using situations, personalities and values, history, heritage, and experience. (4) Brand judgment, regarding the opinion and personal assessment of consumers of the brand and brand image associations they perceive. Aspects of brand judgment include: Brand quality, namely consumer perception of value and perceived satisfaction; Brand credibility, namely how far a brand is considered credible in terms of expertise (competent, innovative, market leader); trustworthiness (reliable, always prioritizing the interests of consumers), and likeability (attractive, worthy of being chosen and used); Brand consideration, which is the extent to which a brand is considered to be bought or used by consumers; Brand superiority, namely the extent to which consumers judge the relevant brand is unique and better than others. (5) Brand feelings, regarding the response and emotional reaction of consumers to the brand. (6) Brand resonance, regarding the relationship characteristics perceived by customers to specific brands.
Resonance is reflected in the intensity or strength of the psychological bond between the customer and the brand, as well as the level of activity arising from this loyalty.

\section{B. Brand Awareness}

Brand awareness can be interpreted as a person's ability to recognize and or recall that a brand is part of a particular product category (Aaker, 1997). The relationship of brand awareness to brand equity depends on the extent to which brand awareness is achieved by the brand. There are four levels of brand awareness consisting of Unaware of Brand where consumers are not aware of a brand, Brand recognition which is the minimum level of brand awareness, Brand recall where consumers can remember brands based on requests to mention certain brands in a product class, and Top of Mind where a brand is the main brand of various brands that exist in consumers' memories (Rangkuti, 2002).

\section{Customer Satisfaction}

Customer satisfaction is one thing that has an important role in business. Customer satisfaction is a major milestone in the success of a company. Therefore, in an effort to meet customer satisfaction, companies must be observant in knowing the shifting needs and desires of consumers that are changing at any time. Consumer satisfaction is a situation that is shown by consumers when they realize that their needs and desires are as expected and well fulfilled (Tjiptono, 2005). Meanwhile, according to (Kotler \& Keller, 2013) Satisfaction is a feeling of pleasure or disappointment someone who appears after comparing the performance (or results) of products thought to the expected performance (or results). If performance fails to meet expectations, consumers will not be satisfied. If the performance is in line with expectations, consumers will be satisfied. If performance exceeds expectations, consumers will feel very satisfied. A consumer may experience various levels of satisfaction, that is if the product is not in accordance with expectations after consumption, then the consumer will feel dissatisfied. But if the opposite happens, the product is in accordance with its expectations, then the consumer will feel satisfied so that one day he will consume the product again. Satisfied consumers are consumers who will share satisfaction with producers. In fact, satisfied consumers will share their tastes and experiences with other consumers. This will be a reference for a product or service. Therefore, both consumers and producers will benefit equally if satisfaction occurs.

\section{Perceived Quality}

Perceived Quality is a dimension of a brand that is very important for consumers to choose the goods and services to be bought (Aaker, 1997). According to (Zeithaml et al., 1988), Perceived Quality is an overall consumer perception (perception) of a product's superiority when compared to its substitute product. From this it can also be seen that perceived quality is the ability of products to be accepted and provide satisfaction to consumers when compared relative to the available substitutions. High perceived quality shows that a consumer has determined the differences and advantages of a product with similar 
products. (Zeithaml et al., 1988) states that perceived quality is a component of brand value where high perceived quality value will encourage consumers to prefer the brand over other brands for similar products.

\section{E. Brand Loyalty}

According to (Schiffman \& Kanuk, 2008), brand loyalty is a consumer preference that consistently purchases products that have certain specifications or service categories on the same brand. According to (Hasan, 2008) in his book entitled Marketing, consumer loyalty is a person who buys, especially people who make purchases repeatedly and regularly, Journal of Business and Management Vol. 4 No.2, June 2017, p 216-227 221 consumer is someone who repeatedly comes to the same place to satisfy his desire by owning a product or service and paying for that product or service and according to (Griffin, 2005) consumer loyalty is a measure which can be relied upon to predict sales growth and also consumer loyalty can be interpreted based on consistent purchases.

\section{METHODOLOGY OF RESEARCH}

In this study, authors used quantitative methods with a descriptive approach. Quantitative research method is one type of research that the specification is systematic, well planned and structured since the beginning of the design of research. According to (Sugiyono, 2013) Quantitative research methods can be interpreted as a research method based on the philosophy of positivism, used to examine on certain populations or samples, sampling techniques are generally performed randomly, data collection using research instruments, quantitative/statistical data analysis with the aim to test a predetermined hypothesis. This research uses a descriptive approach with the aim of describing research objects or research results. According to (Sugiyono, 2012) is a method that serves to describe or give an overview of the objects examined through the collected data or samples without conducting analysis and making the conclusions generally valid. By emphasizing a quantitative approach, this research illustrates the partial and simultaneous influences between the variable brand awareness $\left(\mathrm{X}_{1}\right)$, customer satisfaction $\left(\mathrm{X}_{2}\right)$, and perceived quality $\left(\mathrm{X}_{3}\right)$, to the brand loyalty $(\mathrm{Y})$. This research uses primary data obtained from questionnaires distributed to 66 respondents. The study used multiple regression analyses. This analysis is used to measure the strength of two or more variables and also indicate the direction of the relationship between dependent variables and independent variables. Data is collected, then processed and analyzed using SPSS version 16.0. The population used in this research is the people living in Jakarta and surrounding areas who have purchased based on their own controls or purchased based on their own desires. In addition, the subject also consumes AMDK Pristine brand. Buying and consuming Pristine minimum 1x in a month are considered to represent the consumer loyalty brand to Pristine.

\section{A. Validity test}

A validity test is used to test which questionnaire items are valid and which are invalid (Maida et al., 2017). The validity test in this study was conducted by comparing the value of $r$ arithmetic with $r$ table. If the value of $r$ count is higher than $r$ table, then the question is valid.

\section{B. Reliability Test}

The reliability test is used to show the level of internal consistency reliability by measuring the coefficient of Cronbach's Alpha, where the variable can be categorized as reliable if it has an alpha value higher than 0.60 (Riyanto, 2019).

\section{Multiple Linear Regression Analysis}

This analysis is used to determine the direction of the relationship between the dependent and independent variables, whether each of the independent variables is positive or negative, and to predict the value of the dependent variable when there is an increase or decrease in the independent variable (Maida et al., 2017). The form of the multiple linear regression equation used is as follows:

$$
\begin{array}{ll}
\mathbf{Y}=\mathbf{a}+\mathbf{b}_{1} \mathbf{X}_{\mathbf{1}}+\mathbf{b}_{2} \mathbf{X}_{\mathbf{2}}+\mathbf{b}_{\mathbf{3}} \mathbf{X}_{\mathbf{3}}+\mathbf{e} \\
\mathrm{Y} & =\text { Brand loyalty } \\
\mathrm{A} & =\text { Constant } \\
\mathrm{b}_{1} \ldots \mathrm{b}_{3} & =\text { Regression Coefficients } \\
\mathrm{X}_{1} & =\text { Perceived quality } \\
\mathrm{X}_{2} & =\text { Brand Awareness } \\
\mathrm{X}_{3} & =\text { Customer Satisfaction } \\
\mathrm{E} & =\text { Error }
\end{array}
$$

\section{Descriptive Analysis}

Descriptive analysis is used to analyze data by describing or describing data sets or observations that have been performed so that the data presented is easy to understand and informative. Then the descriptive hypothesis and statistics are formulated as follows:

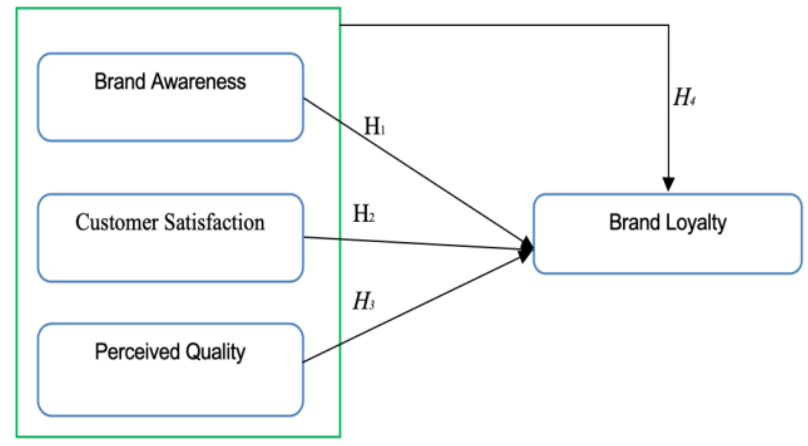

Fig 1:- Framework Model

\section{E. Hypothesis}

H1: Simultaneous brand awareness of brand loyalty

$\mathrm{H} 2$ : Suspected of simultaneous customer satisfaction against the brand loyalty

H3: Simultaneously perceived quality against brand loyalty H4: Allegedly simultaneously brand awareness, customer satisfaction and perceived quality, to the brand loyalty 
ISSN No:-2456-2165

\section{RESULT AND DISCUSSION}

The results of the study were obtained from data processed by using the SPSS 16.0 for Windows application. The validity and reliability of any questions asked to respondents. The Output states that all variables in the study have validity, which all values are already above the $\mathrm{R}$ table ( $\mathrm{r}$ table $=0.2042$ ). From here, it is also known descriptions of characteristics of respondents in the following studies:

\begin{tabular}{|c|c|c|}
\hline Description & Type & Amount \\
\hline Gender & Man & 35 \\
\hline \multirow[t]{4}{*}{ Job } & Students & 6 \\
\hline & Private officer & 37 \\
\hline & Self employed & 9 \\
\hline & Other & 8 \\
\hline \multirow{2}{*}{ Age } & $36-45$ Years & 9 \\
\hline & More than 45 years & 2 \\
\hline \multirow[t]{4}{*}{ Expenses (per month) } & Less than $\mathrm{Rp} 1.000 .000,00$ & 1 \\
\hline & Rp 1.100.000,00 - Rp 2.000.000,00 & 5 \\
\hline & Rp 2.100.000,00 - Rp 5.000.000,00 & 29 \\
\hline & More than $\operatorname{Rp} 20.000 .000,00$ & 29 \\
\hline
\end{tabular}

Table 1:- Description of Research Objective

Source: Data Processing Results 2020

Table 1 obtained the results of data processing and discussion in the research is obtained from the dissemination of questionnaires to 66 respondents who consume AMDK Pristine brand as primary data. The results of descriptive analysis showed that respondents aged 20 years to 25 years as much as 20 respondents $(30.30 \%), 26$ to 35 years as many as 35 respondents (53\%), ages 36 to 45 as many as 9 respondents $(13.60 \%)$ and ages more than 45 years as many as 2 respondents (3\%). Female gender 31 respondents $(47 \%)$ While men were 35 respondents $(53 \%)$. Student work 6 respondents $(9.10 \%)$, civil servants 6 respondents $(9.10 \%)$, private officers 37 respondents $(56.10 \%)$, self-employed 9 respondents $(13.60 \%)$ and others as many as 8 respondents $(12.10 \%)$. Spending less than $\mathrm{Rp} 1,000,000.00$ as many as 3 respondents (4.50\%), $\mathrm{Rp} 1,100,000.00$ to $\mathrm{Rp} 2,000,000.00$ as many as 5 respondents (7.60\%), Rp 2,100,000.00 to Rp $5,000,000.00$ as many as 29 respondents (43.90\%), and more than Rp 5,000,000.00 as many as 29 respondents (43.90\%). This questionnaire consists of 12 question items outlined based on several variables to be researched namely brand awareness Analysis $\left(\mathrm{X}_{1}\right)$, customer satisfaction $\left(\mathrm{X}_{2}\right)$, and perceived quality $\left(\mathrm{X}_{3}\right)$, to brand loyalty $(\mathrm{Y})$. 
ISSN No:-2456-2165

\begin{tabular}{|c|c|c|c|c|}
\hline Variables & Number of Questions & $\begin{array}{c}\text { The range of } \\
\text { value }(\mathbf{r} \text { count) }\end{array}$ & Requirement & Dese \\
\hline Brand awareness $\left(\mathrm{X}_{1}\right)$ & 3 & $0.279-0.745$ & 0.204 & Valid \\
\hline Customer satisfaction $\left(\mathrm{X}_{2}\right)$ & 3 & $0.324-0.802$ & 0,204 & Valid \\
\hline Perceived quality $\left(\mathrm{X}_{3}\right)$ & 3 & $0,302-0.847$ & 0.204 & Valid \\
\hline Brand loyalty $(\mathrm{Y})$ & 3 & $0.342-0.860$ & 0.204 & valid \\
\hline
\end{tabular}

Table 2:- Analysis of Correlation Variables

Source: Data Processing Results 2020

Based on table 2, it can be seen that with a significance level of 5\% acquired $\mathrm{R}$ table value of 0.2042 . In the table, the validity test for the $X_{1}$ variable that is a brand awareness variable indicates that the variable has a $r$ count value of $0279-0745$ where the value is greater than the $\mathrm{R}$ table value, so that the $\mathrm{X}_{1}$ variable is considered valid. The validity test for a variable $X_{2}$ that is customer satisfaction indicates that the variable has a $r$ count value of 0324 - 0802 where the value is greater than the $\mathrm{R}$ table value, so that the variable $\mathrm{X}_{2}$ is considered valid. The validity test for the $X_{3}$ variable that is perceived quality indicates that the variable has a $\mathrm{r}$ count value of $0.302-$ 0847 where the value is greater than the $\mathrm{R}$ table value, so the $\mathrm{X}$ Variable is considered valid. Likewise, with the validity test for variable $\mathrm{Y}$ that is a variable brand loyalty has a $R$ count value of 0342-0860 where the value is greater than the value of $\mathrm{R}$ table, so that the variable $\mathrm{Y}$ is considered valid.

\section{A. Reliability Test}

Reliability test results based on Cronbach's Alpha formula can be seen in the table below.

\begin{tabular}{|c|c|c|c|}
\hline Variable & Reliability Coefficient & Critical Point & Information \\
\hline Brand awareness $\left(\mathrm{X}_{1}\right)$ & 0.759 & 0.6 & Reliable \\
\hline Customer satisfaction $\left(\mathrm{X}_{2}\right)$ & 0.850 & 0.6 & Reliable \\
\hline Perceived quality $\left(\mathrm{X}_{3}\right)$ & 0.752 & 0.6 & Reliable \\
\hline Brand loyalty $(\mathrm{Y})$ & 0.764 & 0.6 & Reliable \\
\hline
\end{tabular}

Table 3:- The Result of Reliability Test

Source: Data Processing Results 2020

According to the table above, it can be seen that the brand awareness $\left(\mathrm{X}_{1}\right)$ variable, customer satisfaction $\left(\mathrm{X}_{2}\right)$, and perceived quality $\left(\mathrm{X}_{3}\right)$, on brand loyalty $(\mathrm{Y})$ has a coefficient value greater than 0.60 with the value of each variable of 0759 for the variable brand awareness $\left(\mathrm{X}_{1}\right)$, 0850 for customer satisfaction variables $\left(\mathrm{X}_{2}\right), 0752$ for the variable perceived quality $\left(\mathrm{X}_{3}\right)$, and 0764 for the variable brand loyalty (Y). From these results, all four variables can be said to be reliable.

\section{B. Multiple Linear Regression Analysis}

The results of multiple linear regression analyses can be seen in the table below.

\begin{tabular}{|c|c|c|c|c|c|c|}
\hline \multicolumn{7}{|c|}{ Coefficients $^{\text {a }}$} \\
\hline \multirow{2}{*}{\multicolumn{2}{|c|}{ Model }} & \multicolumn{2}{|c|}{ Unstandardized Coefficients } & \multirow{2}{*}{$\begin{array}{c}\text { Standardized Coefficients } \\
\text { Beta } \\
\end{array}$} & \multirow[t]{2}{*}{$\mathrm{t}$} & \multirow[t]{2}{*}{ Sig. } \\
\hline & & B & Std. Error & & & \\
\hline \multirow[t]{4}{*}{1} & (Constant) & .498 & .390 & & 2.276 & .207 \\
\hline & Brand Awareness $\left(\mathrm{X}_{1}\right)$ & .134 & .089 & .151 & 3.502 & .138 \\
\hline & $\begin{array}{c}\text { Customer satisfaction } \\
\left(\mathrm{X}_{2}\right)\end{array}$ & .192 & .114 & .192 & 2.686 & .097 \\
\hline & Perceived Quality $\left(\mathrm{X}_{3}\right)$ & .501 & .103 & .519 & 4.852 & .000 \\
\hline \multicolumn{3}{|c|}{ a. Dependent Variable: Brand Loyalty (Y) } & & & & \\
\hline
\end{tabular}

Table 4:- The Result of Reliability Test

Source: Data Processing Results 2020 
Based on the table above can be written into the form of multiple linear regression equations as follows:

$Y=7.097+2.069 X_{1}+2.463 X_{2}$

According to the table above, it can be seen that the brand awareness $\left(\mathrm{X}_{1}\right)$ variable has a calculated $\mathrm{T}$ value of 3,502 with a table $T$ value of 1,990 . This indicates that the $\mathrm{X}_{1}$ variable has a significant effect on the brand loyalty because the value of the calculated $\mathrm{T}$ is greater than the table $\mathrm{T}$ value. Whereas, a competitive advantage variable $\left(\mathrm{X}_{2}\right)$ has a calculated $\mathrm{t}$ value of 2,685 with a table $\mathrm{T}$ value of 1,990 where it indicates that the variable $X_{2}$ has a significant effect on brand loyalty because the value of the calculated $\mathrm{T}$ is greater than the table $\mathrm{T}$ value. And, whereas, a variable competitive advantage $\left(\mathrm{X}_{3}\right)$ has a calculated $t$ value of 4,852 with a table $T$ value of 1,990 where it shows that the $X_{3}$ variable has a significant effect on brand loyalty because the value of the calculated $\mathrm{T}$ is greater than the table's $T$ value.

\begin{tabular}{|c|c|c|c|c|c|c|}
\hline \multicolumn{7}{|c|}{ ANOVA $^{b}$} \\
\hline \multicolumn{2}{|r|}{ Model } & $\begin{array}{l}\text { Sum of } \\
\text { Squares }\end{array}$ & $\mathrm{df}$ & $\begin{array}{l}\text { Mean } \\
\text { Square }\end{array}$ & $\mathrm{F}$ & Sig. \\
\hline \multirow[t]{3}{*}{1} & Regression & 14.340 & 3 & 4.780 & 23.439 & $.000^{\mathrm{a}}$ \\
\hline & Residual & 12.644 & 62 & .204 & & \\
\hline & Total & 26.985 & 65 & & & \\
\hline \multicolumn{7}{|c|}{$\begin{array}{l}\text { a. Predictors: (Constant), Perceived Quality }\left(\mathrm{X}_{3}\right) \text {, Customer } \\
\text { satisfaction }\left(\mathrm{X}_{2}\right), \text { Brand Awareness }\left(\mathrm{X}_{1}\right)\end{array}$} \\
\hline \multicolumn{4}{|c|}{$\begin{array}{c}\text { b. Dependent Variable: Brand } \\
\text { Loyalty (Y) }\end{array}$} & & & \\
\hline
\end{tabular}

Table 5:- The Result of F-Test

Source: Data Processing Results 2020

Based on the table above indicates that the value $\mathrm{F}$ count obtained is 23.439 with a value of $F$ table of 2,750. This suggests that the working culture variables and competitive advantages have a significant (simultaneous) influence on the business performance variables as it has an $\mathrm{F}$ value count greater than the $\mathrm{F}$ table.

\begin{tabular}{|c|c|c|c|c|}
\hline \multicolumn{5}{|c|}{ Model Summary } \\
\hline Model & $\mathrm{R}$ & R Square & $\begin{array}{c}\text { Adjusted R } \\
\text { Square }\end{array}$ & $\begin{array}{c}\text { Std. Error of the } \\
\text { Estimate }\end{array}$ \\
\hline 1 & $.729^{\mathrm{a}}$ & .531 & .509 & .45160 \\
\hline \multicolumn{5}{|c|}{ a. Predictors: (Constant), Perceived Quality $\left(\mathrm{X}_{3}\right)$, Customer } \\
satisfaction $\left(\mathrm{X}_{2}\right)$, Brand Awareness (X)
\end{tabular}

Table 6:- The Result of the Coefficient of Determination Source: Data Processing Results 2020

From the table above we can get the coefficient of determination as follows:

$\mathrm{KD}=\mathrm{R}^{2} \times 100 \%$

$=(0.729)^{2} \times 100 \%$

$=53.14 \%$
Based on the above calculations can be seen that the variable brand awareness $\left(\mathrm{X}_{1}\right)$, customer satisfaction $\left(\mathrm{X}_{2}\right)$, and perceived quality $\left(\mathrm{X}_{3}\right)$, has a simultaneous effect of $53.14 \%$ against the variable on brand loyalty $(\mathrm{Y})$, while the remaining $46.86 \%$ is affected by other factors that are not researched in this study.

\section{CONCLUSION}

The conclusion of the study is:

The results of a partial analysis indicate that the brand awareness variable has a significant effect on the consumer loyalty brand AMDK brand Pristine.

$>$ Simultaneous analysis results showed that the variable customer satisfaction significantly affects the brand loyalty consumer AMDK brand Pristine.

- Simultaneous analysis results showed that the variable perceived quality has a significant effect on the brand loyalty consumer AMDK brand Pristine.

$>$ Simultaneous analysis results showed that the variables of brand awareness, customer satisfaction, and perceived quality have a significant effect on the brand loyalty consumer AMDK brand Pristine.

\section{REFERENCES}

[1]. Aaker, D. (1997). Managing Brand Equity. The Free Press.

[2]. Aaker, D. (1997). Manajemen Ekuitas Merek. Mitra Prentice Hall.

[3]. Griffin, J. (2005). Customer Loyalty (Menumbuhkan dan Mempertahankan Kesetiaan Konsumen). Erlangga.

[4]. Hasan, A. (2008). Marketing. Media Utama.

[5]. Hasugian, J. (2015). "Pengaruh Brand Image dan Brand Trust Terhadap Brand Loyalty Telkomsel Survei Terhadap Pelanggan Telkomsel di Grapari Samarinda." Jurnal Ilmu Administrasi Dan Bisnis, Vol. 3(Issue 4).

[6]. Kotler, P., \& Keller, K. L. (2013). Manajemen Pemasaran (Jilid Kedua). Airlangga.

[7]. Lee, J., \& Ki, J. (2010). "Reexamination of AttendeeBased Brand Equity.” Tourism Management, Vol.31 (Issue 3).

[8]. Madden, T., Frank, F., \& Susan, F. (2006). "Brands Matter: An Empirical Demonstration of The Creation of Shareholder Value Through Branding." Journal of the Academy of Marketing Science, Vol. 34 Is.

[9]. Maida, M., Riyanto, S., \& Ali, H. (2017). Effect of Job Satisfaction and Leadership Style Towards Employee Productivity at PT General Insurance Bumiputera Muda 1967. Saudi Journal of Business and Management Studies.

[10]. Mariadi, \& Aima. (2014). Pengaruh Brand Equity, Persepsi Harga, dan Distribusi Terhadap Kepuasan Pelanggan Produk Pakaian Merek Old Blue Company.

[11]. Pappu, R., Pascale, G., \& Ray, W. (2005). "Consumer-Based Brand Equity: Improving The Measurement -Empirical Evidence." Journal of Product \& Brand Management, Vol 14(Issue 3). 
[12]. Rangkuti, F. (2002). The Power of Brand: Teknik Mengelola Brand Equity dan Strategi Pengembangan Merek. Gramedia Pustaka Utama.

[13]. Riyanto. (2019). The Impact of Leadership, Organizational Culture and Organizational Climate on Employee Job Satisfaction. Advances in Economics, Business, and Management Research. Vol. 120.

[14]. Satria, M. M., Catur, P., Sukohar, A., Kedokteran, F., \& Lampung, U. (2016). Air Alkali Terionisasi Pencegahan Termutakhir Timbulnya Kanker Ionized Alkaline Water as the Latest Prevention of Cancer Emergence. 5(April).

[15]. Schiffman, L., \& Kanuk, L. L. (2008). Perilaku Konsumen. Indeks.

[16]. Sugiyono. (2012). Metode Penelitian Bisnis. Alfabeta.

[17]. Sugiyono. (2013). Metode Penelitian Kuantitatif, Kualitatif dan R\&D. Alfabeta.

[18]. Tjiptono, F. (2005). Brand Management \& Strategy. ANDI.

[19]. Yasin, N., Mohd, N., \& Osman, M. (2007). "Does Image of Country-of-Origin Matter to Brand Equity." Journal of Product \& Brand Management, Vol. 16 Is.

[20]. Zeithaml, L., Valerie, A., Parasuraman, A., Leonardo, L., \& Berry. (1988). Servqual a multiple- item scale for measuring consumer perception of service quality. Journal of Retailing. 